University of Nebraska - Lincoln

DigitalCommons@University of Nebraska - Lincoln

2013

Digital Gravescapes: Digital Memorializing on Facebook

Scott H. Church

University of Nebraska-Lincoln, scotthchurch@gmail.com

Follow this and additional works at: https://digitalcommons.unl.edu/commstudiespapers

Church, Scott H., "Digital Gravescapes: Digital Memorializing on Facebook" (2013). Papers in Communication Studies. 37.

https://digitalcommons.unl.edu/commstudiespapers/37

This Article is brought to you for free and open access by the Communication Studies, Department of at DigitalCommons@University of Nebraska - Lincoln. It has been accepted for inclusion in Papers in Communication Studies by an authorized administrator of DigitalCommons@University of Nebraska - Lincoln. 


\title{
Digital Gravescapes: Digital Memorializing on Facebook
}

\author{
Scott H. Church \\ Department of Communication Studies, University of Nebraska-Lincoln, Lincoln, Nebraska, USA \\ Correspondence: 2110 Oak Haven Pl., Sandy, UT 84093-1034, USA, email scotthchurch@gmail.com
}

\begin{abstract}
I conduct a textual analysis of a digital memorial to understand the ways in which the digital sphere has disrupted or altered material and aesthetic displays of death and the associated genre of discourses surrounding death. I first use Morris's history of traditional gravescapes to situate digital memorials within their broader historical context. I then draw on the functional genre of eulogies, in particular Jamieson and Campbell's systematic description of eulogies, as a textual analytic to understand Facebook's unique memorializing discourse. My analysis suggests that the affordances of the Internet allow for a peculiar dynamic wherein the bereaved engage in communication with the deceased instead of with each other and yet strengthen the communal experience, as their personal communications are visible to the entire community. While the digital memorials lack the permanence of traditional gravescapes, the ongoing conversation they foster sublimates death into the process of communication.
\end{abstract}

Keywords: Facebook, death, gravescapes, eulogy, discourse, memorializing, digital media, rhetoric

In December 2008 I received the news of a fatal skiing accident of one of my close friends from school, Clarissa Stone. ${ }^{1}$ She was also one of my friends on the social network site Facebook, where, incidentally, I heard of her death. I subsequently looked at her Facebook profile page and was struck by how her status update, posted just three days before her death, had assumed a morbid irony: "[Clarissa] is skiing freshness for the next mannny [sic] days." Unexpectedly, I found myself at an incongruous space where the dead person was still in the presence of the living and seemingly communicating from the grave.

Here we see that the inevitable occurrence of death, once a taboo topic of conversation usually confined to quiet rooms in hospitals, now manifests itself publicly in mediated social spaces in the form of digital memorials (Gibson 2011; Hanusch 2010). This new phenomenon of digitalmemorializing displays a curious interplay between the discourses of material (permanent) death displays and the ephemeral memorializing (pseudopermanence) of Internet culture. Facebook, MySpace, Virtual Eternity, and MyDeathSpace are a few examples of websites that enable continued "dialogue" between the mortal and postmortal by allowing "interaction" with the deceased. ${ }^{2}$

According to boyd and Ellison (2007), profiles on social network sites are unique spaces "where one can type oneself into being" (online, para. 6). Conversely, profiles of deceased users allow communities to type the deceased back into being. In the digital culture of remembrance, then, these social network sites function as spaces of remembrance, efficient vehicles to distribute messages to a mass audience, and loci for the mediated construction of affiliation in a community of bereavement.

I focus on Facebook as the particular text of analysis because of its immense popularity and large number of users who have passed away: It now has 800 million active users worldwide (Facebook 2011), and it is estimated that 1 to 1.5 million of those Facebook users died in 2010 (Good 2010). Further, digital memorials on Facebook are distinctly aesthetic because they display vivid visual and discursive representations of their once-living creators. In effect, they are highly textured sites of "networked grief" (Vealey 2011). To better understand the nature of these digital gravescapes, I conduct a textual analysis of the Wall of Clarissa's private profile. ${ }^{3}$

My investigation is directed at understanding the ways in which the digital sphere has disrupted or altered 
material and aesthetic displays of death and the associated genre of discourses surrounding death. I first draw on RichardMorris's (2006) history of traditional gravescapes to situate digital memorials within their broader historical context. I then employ the functional genre of eulogies, in particular Jamieson and Campbell's (1982) systematic description of eulogies, as a textual analytic to understand Facebook's unique memorializing discourse.

\section{Antecedents to Digital Memorials in Western Culture $^{4}$}

In the fourth century BCE, poets in ancient Greece wrote elegiac poems for the dead. This genre of sepulchral epigrams essentially made explicit what the gravestone symbolized: There is a presence of the dead among the living (Bruss 2005). Throughout the Classical and Middle Ages, death rituals were bifurcated along religious and secular lines. Biblical texts like the four gospels, the book of Isaiah, and the writings of Paul presented a discursive repertoire from which mourners could draw (Phipps 1987; Sawyer 1994). In this use of religious discourse, the deceased who were faithful were envisioned as beneficiaries of Christ's sacrifice and subsequent miracle of resurrection. Pagan societies appear to also have believed in some sort of afterlife; their gravesites would often be adorned by mementos, suggesting that perhaps the deceased could take their possessions to the next life. Their inscriptions on gravestones largely addressed continuities of affection and familial relationships after death (Harvey 1994).

Historically, visual displays of death educated the viewer about mortality. According to Richard Morris's (2006) history of these displays of death, a gravescape is composed of a physical memorial and its surrounding landscape. These memorials or "sacred symbols" not only serve to retain the life of the deceased in the public memory, but also to epitomize "the ethos and worldview of the gift-giver" (204). In this way, the gravescape rhetorically constructs and maintains how the deceased should be remembered via the aesthetic display of the memorial and landscape. From the beginning of colonization to the early 19th century, cemeteries were generally monopolized by the memento mori display. The cultural worldview expressed by the memento mori to its viewer was that life is fragile; often the display included the phrase fugit hora, reminding all that "time flies." These gravesites and memorials also included iconographic images of the macabre, including skulls, crossed bones, andwinged creatures. The purpose of these images, however, was not to terrify the viewer but to instill a reminder in him or her of the inevitability of death.

Originating in the mid-18th century, the garden romance display, in contrast, portrayed death to be inspirational and beautiful, as much a natural part of life as breathing. These displays were characterized by intricate gardening flourishes and statues to instigate awe in the auditor at the aesthetic beauty of art and nature. This garden display used pathos, "impel[ing] viewers toward sublime and homeopathic feelings, thoughts, and attitudes" (Morris 2006, 210). Closely associated with these attitudes would be the yearning for a community among the living, thereby bringing mourners together to be unified with each other and with nature. As such, they would view nature and appreciate its inherent unity even while being faced by the disunity and chaos of death. The life of the deceased would be celebrated as an extension of nature and art; instead of the somber emotions evoked by the memento mori memorial, the viewers of these garden displays instead might feel pleasure and emotional satisfaction. Furthermore, its pathetic appeal focused on their similarities with the deceased, minimizing differences between the living and the dead through a display both egalitarian and aesthetic. These sober responses to the natural helped subdue the fear of death in the bereaved.

\section{Digital Bereavement Communities}

The symbolism of unity and community evoked by the garden romance gravescape became more explicit with memorials in the digital age. Pamela Roberts's (2004) often-cited article on "virtual cemeteries" articulates three ultimate functions of online bereavement communities: to continue bonds with the dead, to strengthen relationships with the living, and to create newcyberspace communities. In order to maintain these bonds with the dead, mourners address messages to loved ones who have passed on, often by leaving messages in online virtual guest books. This practice parallels the earlier pagan practices of leaving notes and mementos on gravestones. Indeed, the living may share "updates" of their lives with the dead; cases have been documented where widow(er)s bring fiancé(e) $\mathrm{s}$ to cemeteries to introduce former and future spouses to each other (Roberts 2004). Online memorials also may strengthen existing ties between mourners; messages left therein might create a sense of solidarity with the other mourners (and construct communities with strangers who happen upon these sites as well). This phenomenon could be likened to a mediated "imagined community," hailed into existence by a common sense of purpose (Anderson 1983).

\section{Textual Analysis of a Digital Memorial}

Within the context of digital memorials, Facebook presents a peculiar space: It is a space for intimate communion between the living and the dead and also a space for fostering communal relationships among the 
living. Here the functional genre of eulogies is a useful hermeneutic, as it arises out of the material discourse of memorializing and can function as a contrast to the discourse of digital memorials.

I used Jamieson and Campbell's (1982) description of the rhetorical genre of eulogies as a textual analytic to examine responses to death on Facebook. These responses included all of the posts on the Wall of Clarissa's private memorial for the three years following her death. In accordance with Facebook's privacy policy, the visibility of a user's account is restricted when it is memorialized. Only confirmed friends are able to view (and search for) the profile, and it will not appear to nonfriends in their "People You May Know" feeds. The bereaved community may create status updates about the deceased on their own pages, though the option to tag the deceased in a status update does not appear to exist. ${ }^{5}$ As such, if Clarissa was mentioned in a friend's post (but not tagged), the post was not accessible on her Wall and thus was not included in the analysis. Friends, however, may tag the deceased in pictures or in notes. If the deceased is tagged, the associated activity will appear on the Wall. I did not include the tagged pictures of Clarissa in the number of total posts analyzed because they did not contain any written utterances. However, these tagged photo posts contributed to the overall aesthetic display of the memorial by supplementing the identity markers that adorn the page.

In the final years of her life, Clarissa had a moderate presence in social media. She had personal Facebook and MySpace pages and used them to connect with friends and family. In the 16 months following the activation of her account on Facebook, she received 148 posts on her Wall from a small group of her roughly 250 Facebook friends. Most of these notes were brief, informal, and reminiscent of short face-to-face verbal exchanges. When news of her death began to spread through local and national news outlets, however, she received a barrage of Wall posts: 80 posts were recorded within the first 24 hours after news broke of the tragedy. When one post asked for answers or clarification, another one provided the necessary details. Almost immediately after her death, for example, a friend posted the incredulous message on her Wall: "TELL ME IT ISN'T TRUE :(()((()((." This was followed by another friend's post within half an hour solemnly declaring: "It is." Nine minutes later, the messages to Clarissa began in earnest: "you will be missed ..." and "Heart broken." In addition to these intimate notes expressing concern for Clarissa, many of the early posts evinced a shared feeling of disbelief: "This is unreal ...," "I just talked to you the other day ...," "I'm still in shock.. Is this real?" "[Clarissa] is (I can't even post was) an amazing friend ..." (emphasis added). Such expressions of disbelief continued on her Wall for years following the tragedy; often, friends posted that they thought they saw Clar- issa peripherally or heard her laugh in the background. Over three years, 10 separate posts recounted dreams about her.

As a generic convention, traditional eulogies commemorating the dead "will acknowledge the death, transform the relationship between the living and the dead from present to past tense, ease the mourners' terror at confronting their own mortality, console them by arguing that the deceased lives on, and reknit the community" (Jamieson and Campbell 1982, 147). On the whole, the generic expectations for the posts on Clarissa's Wall appeared to operate dialectically. Initially the discourse followed the generic convention of eulogies and acknowledged the death. Roughly a day later and thereafter, however, friends and family began addressing pictures and letters to the deceased as if she were still present to receive them. Thus, the discourse began to violate generic conventions when Clarissa was no longer discursively framed as dead.

The second element of the genre was also first performed and then disrupted: References to the deceased changed from present to past, and then reverted from past back to present. Indeed, over the years after her death, not only did the friends write overwhelmingly in present tense as if Clarissa were alive, they sought to share the significant (and often banal) details of their lives with her: a great experience skiing, getting married, having a child, studying for final exams. Two friends stated with a sense of relief that her page existed as a place to commune, while another acknowledged the importance of her digital presence: "I have three voice messages from you on my cell phone. That is good. I can still listen to you. You are still with me." The same friend also displayed ambivalence about the Facebook site, cursing it in one post ("it hurts so much to click on your page") and yet acclaiming it in another ("I am so glad that I have this place to talk to you"). Another felt a difficulty in reconciling the loss of her friend, who still ostensibly remained in her life because of digital media: "still can't really figure out how to deal with you being memorialized ... (is that a word). $\mathrm{i}$ almost sent you a text yesterday. i have so much to tell you." Though her wall offered a locale for her friends and family to eulogize her to the community, they chose instead to engage in the modality of continued communication with her.

Third, and further disrupting the genre, the community that was reknit initially in the early posts was subsequently downplayed. The frequency of posts directed to the community, which was never high, decreased and disappeared completely after a short time when the focus of the posts turned to addressing Clarissa. Only several years after the tragedy, once her mother started posting frequently on the wall, did messages begin to appear that were vaguely aimed at the community.Out of the 365 Wall posts analyzed in the three years since 
the tragedy, only 14 were not addressed specifically to Clarissa, and only 8 of those were addressed to the entire community. The messages aimed at the community were strictly utilitarian rather than eulogistic, telling the other friends where to find her obituary and where to attend the funeral service. One message addressed to the community by Clarissa's sister indicated the therapeutic power of the site: "I had the facebook people memorialize [Clarissa]'s account, so she will be here forever. My family is enjoying reading all of these wonderful writings! Thanks!"

In my estimation, the reason why eulogies were such a small portion of the messages on Clarissa's Wall is that the digital medium offers an illusion of two-way communication, and that works against traditional eulogizing. The digital space created by Clarissa maintained the same aesthetic appearance after her death as it did during her life; there was no physical casket or headstone to reinforce the reality of death; only her vibrant pictures and words remained. The traditional eulogy addresses a community of mourners, whereas the digital gravescape allows that community of mourners to deflect their attention from each other to the deceased.

\section{The Digital Gravescape}

Of the types of material death displays identified by Morris (2006), Facebook memorials most closely resemble the garden romance gravescape, functioning largely as spaces to celebrate life and commune with the dead. However, there are a few important differences between the physical and digital garden displays. First, as mentioned, the digital gravescape downplays its communal function. Second, the digital gravescape is devoid of aesthetics conventionally associated with memorials. In their absence, the photographs and written text by the deceased create a new brand of digital sublimity for the bereaved. Thus, the digital landscape is adorned with its own unique aesthetic. For example, many of the electronic posts by Clarissa's grieving friends included visual imagery of the afterlife as endless mountains of snow and other such motifs of pristine nature. Here art is equated with the expression of feelings in the ethos of the viewer of the garden romance display. Therefore, I suggest that Facebook offers a new dematerialized gravescape - the "aesthetic identity display," which shifts identity from material to immaterial life. The deceased essentially created a perpetual online presence upon signing into these sites and creating a display. However, the viewer of these sites after the creator's death also performs an identity as member of a close-knit community, facilitated by Facebook's memorializing features. When the identity of the living creator shifts from mortal to postmortal, the cosmic realities that govern temporal space change. However, the digital identity maintains itself, still fluid and pres- ent to the community. Unlike that in the material incarnation of the garden romance display, this community is ostensibly a silent community, one that functions as a witness to the communications on the memorial but abstains from communicating with each other publicly on the memorial. ${ }^{6}$

\section{Permanence and Place}

When discourses surrounding death are transferred from the material to the digital context, the temporality of the Internet poses peculiar challenges because the digital gravescape is less permanent than the physical gravescape. Though it may seem impossible to erase one's online presence, the Internet is perpetually shifting and obscuring old pages and sites. When one site is upgraded, the old site ostensibly disappears, although many pages are cached by the InternetArchive. In effect, the Internet is biased toward a vastness of data at the marked expense of permanence. Put another way, digital archives are "full of wholes [and] yet simultaneously full of holes" (Kidd 2009, 180). According to Jones (2004), the easy archival of information that the medium affords is rendered less valuable by the sheer amount of information in its repository. Drawing on these ideas, I argue that there is a continuum of permanence in memorializing practices. The physical gravesite, carved out of stone or constructed as architecture, is the most permanent. The obituary, printed on paper, is less permanent. The official memorializing website is even less permanent because it exists solely in cyberspace. The vernacular memorializing website is less permanent than the official one because of the lack of designated gatekeepers, though Facebook's recent policies appear to make more of an effort to do so.

Digital memorials are also less bound by locality than physical gravescapes. For example, in the case of physical gravescapes, public memorials tend to benefit from proximity to places of significance (Mori, Howard, and Gibbs 2011).When these sites are shifted into the digital sphere, however, that local anchoring is lost and the digitalmemorial is decontextualized. Though the profiles created in life by the deceased are extremely personal, as digital memorials they lack the geographic and cultural specificity that gives the material memorials their character. Perhaps because of this, the sense of community is overshadowed on Facebook by the desire of the bereaved to communicate with the dead. Therefore, reminiscence takes precedence over locality and community.

There is a sense of community on Facebook in that the mourners can panoptically view all of the others and their respective communications; however, at least in the case presented here, the dead person remains the focus of attention over the community. This focus on communicating with the dead rather than with the community may also be due to the medium; the grieving have 
the added benefit of having their "private" messages to the dead also appear publicly to others. This private/ public modality establishes a public identity of one's self as attending to the dead while creating a display of networked grief with each wall posting.

\section{Conclusion: Overcoming Death}

The digital gravescape has elements of the memento mori display and the garden romance display, yet its lack of permanence is at variance with the whole purpose behindmaterial memorials. The garden display gravescape is closer to the memorials on Facebook, where a life is celebrated and family and friends partake in a place designated to commune with the dead. The text of these memorials, supplemented by photos and personalized information about the deceased, adds to the sublimity of the experience for the bereaved. The affordances of the Internet allow for a peculiar dynamic wherein the bereaved engage in communication with the deceased instead with each other and yet strengthen the communal experience, as their personal communications are visible to the entire community.

Despite the temporality of digital memorials, these displays of death allow for the termination of the mortal life to be overcome by the immortal process of communication. In other words, these digital gravescapes overcome the material restrictions of death by facilitating continued communication between the grieving and the dead. Media's historic potential to facilitate dialogue in the 19th century may be summarized in the following terms: "the photograph overcame time and the telegraph overcame space" (Peters 1999, 138). ${ }^{7}$ Cautiously, I would add to the scholarly conversation that in the 21st century, the Internet overcame death (or at least provided that illusion). With the ubiquity of social network sites, the user is not only appropriating and personalizing a space for him- or herself, he or she is also effectively creating an aesthetic identity gravescape whereupon future members of the community may come to observe traces of that presence.

\section{Notes}

1. Clarissa had been skiing in a treacherous area when an avalanche took her life at age 27. Her name has been changed out of respect for the individual and her friends and family.

2. The Facebook application IfIDie.net, for example, allows users to create messages and have them released to their friends posthumously.

3. The Wall is a section on the user's profile page that is dedicated to receiving posts from friends.

4. The sample I have included here is far from comprehensive; it is, however, intended to sketch in broad strokes the historical context within which digital memorializing can be situated.
5. More information can be found regarding Facebook's memorializing policy on its help center page at http://www. facebook.com/help/?page $=185698814812082$

6. It should be noted that Facebook friends are also able to send private messages to deceased users on memorialized pages. Though these messages may exist, they were not available as a Wall post and thus were not included in this analysis. Similarly, the bereaved Facebook friends could have communicated with each other via privatemessages; however, these exchanges were absent from the Wall of the memorial and thus were not considered in the analysis.

7. Peters acknowledges that this statement is too stark. However, I believe Peters's near-hyperbole serves a useful purpose because of its very starkness, as it pithily captures essential elements of the changes brought about in the 19th century with the help of communications technologies.

\section{References}

Anderson, B. 1983. Imagined communities: Reflections on the origin and spread of nationalism. New York, NY: Verso Books.

Bruss, J. S. 2005. Hidden presences: Monuments, gravesites, and corpses in Greek funerary epigram. Dudley, MA: Peeters.

boyd, d. m., and N. B. Ellison. 2007. Social network sites: Definition, history, and scholarship. Journal of Computer-Mediated Scholarship 13: article 11.

Facebook. 2009. Personal correspondence between the author and Clint, in the User Operations Department of Facebook. E-mail received on April 2.

Facebook. 2011. Facebook now has more than 800 million active users. Information by StatSpotting application. September 22. http://www.facebook.com/notes/ statspotting/facebook-now-has-more-than-800-million-active-users/204500822949549 (accessed June 8, 2012).

Gibson, M. 2011. Death and community. In Governing death and loss: Empowerment, involvement, and participation, ed. S. Conway, 15-25. New York, NY: Oxford University Press.

Good, J. 2010. The rise of the dead: How many ghosts are on Facebook? Blog post for 1000memories.com. November 18. http:/ / 1000memories.com/blog/22-the-rise-of-the-deadhow-many-ghosts-are-on-facebook (accessed June 8, 2012).

Hanusch, F. 2010. Presenting death in the news: Journalism, media and mortality. New York, NY: Palgrave Macmillan.

Harvey, G. 1994. Death and remembrance in modern Paganism. In Ritual and remembrance: Response to death in human societies, ed. J. Davies, 103-22. Sheffield, UK: Sheffield Academic Press.

Jamieson, K. H., and K. K. Campbell. 1982. Rhetorical hybrids: Fusions of generic elements. Quarterly Journal of Speech 68: 146-57.

Jones, S. 2004. 404 not found: The Internet and the afterlife. Omega 49(1): 83-88.

Kidd, J. 2009. Digital storytelling and the performance of memory. In Save as ... digital memories, ed. J. Garde-Hansen, A. Hoskins, and A. Reading, 167-83. New York, NY: Palgrave Macmillan. 
Mori, J., S. Howard, and M. Gibbs. 2011. Poets and blacksmiths: Implications for global memorialization using digital technology. interactions. September + October. doi:10.1145/2008176.200 8188 .

Morris, R. (2006). Death on display. In Rhetorics of display, ed. L. J. Prelli, 204-226. Columbia, SC: University of South Carolina Press.

Peters, J. D. 1999. Speaking into the air: A history of the idea of communication. Chicago, IL: University of Chicago Press.

Phipps,W. E. 1987. Death: Confronting the reality. Atlanta, GA: John Knox Press.
Roberts, P. 2004. The living and the dead: Community in the virtual cemetery. Omega 49(1): 57-76.

Sawyer, J. F. A. 1994. Isaiah as a source book for scriptural texts about death and mourning. In Ritual and remembrance: Response to death in human societies, ed. J. Davies, 86-102. Sheffield, UK: Sheffield Academic Press.

Vealey, K. 2011. Making dead bodies legible: Facebook's ghosts, public bodies and networked grief. Gnovis XI(II). http://gnovisjournal.org/2011/04/03/making-dead-bodies-legible (accessed June 8, 2012). 